tilbagevendende pointe om ikke at ville forklare nazismen burde dog måske afholde ham fra at tale om bevægelsens drivkraft? Et af de afgørende spørgsmål i folkemordsforskningen er jo, om nazisterne fra starten stræbte mod holocaust. Gosvig Olesen synes at forbigå dette spørgsmål ved at argumentere, at nazismen, som rabiat antisemitisme, ikke havde indbyggede begrænsninger, og derfor fandt holocaust sted. Der bliver dog hverken skelnet mellem forskellige tidspunkter, forskellige steder eller forskellige personer. I Gosvig Olesens egen sprogbrug kunne man spørge, på præcis hvilken måde fænomenet Hitler og begivenheden holocaust er forbundet? Hvis man vil tale om, hvilken mulighed, der åbnede sig, må man vel forst analysere, hvilken begivenhed, som blev mulig. Med andre ord, hvad er det egentlig, vi ved, som skete?

Bogen fremfører altså en fortolkning, som den selv har problemer med at underbygge. Der kan naturligvis argumenteres for sådanne fortolkninger, men det afgørende er, at alle sådanne argumentationer nødvendigvis må gøre brug af videnskabelige analyser, der alle søger at give den bedst mulige forklaring inden for sine egne begrænsninger. Det forsvar for den frie tænkning, som bogen i virkeligheden er, ender altså med at pege på sin egen begrænsning.

Derfor er betegnelsen "introduktion" ikke særlig velvalgt, for i stedet drejer det sig egentlig om en demonstration af, hvad man med en sådan filosofisk tilgang kan tænke om fænomenet 'Hitler'. Bogen indbyder til at tænke med, mod og videre, hvilket er en beundringsværdig bedrift, og den lykkes til fulde med at vise, at nazismen som begivenhed stadig stiller afgørende spørgsmål til vores nutid. Det er netop derfor lidt synd, at bogen ikke forsøger at indgå i en mere konstruktiv diskussion med de videnskabelige tilgange, som stadig søger at uddybe vores forståelse af holocaust. Holocaustforskningen giver nemlig endnu i dag noget at tænke over.

MARTIN BLOK JOHANSEN

Tid og eksistens hos Kierkegaard og Heidegger

Wenche Marit Quist: Tid og eksistens. Kierkegaard og Heidegger, Anis, 2009, 355 sider, 289,- kr.

I forordet til Frygt og Baven skriver Søren Kierkegaards meget lidt tavse talerør, Johannes de silentio, at såfremt man vil være en forfatter, der vil have læsere, så må man 
skrive således, "at det beqvemt lader sig gjennemblade under Middagssøvnen”. Wenche Marit Quist, der er forfatter til Tid og eksistens. Kierkegaard og Heidegger, har ikke bestræbt sig på at efterkomme denne opfordring. Det er skønt, for midt i slipstrømmen af de utallige bøger om Kierkegaard, der for tiden stævner ud fra diverse forlag, er denne bog på mange måder nyskabende. Dette er ikke en introduktion eller en biografi. Det er en bog med et tematisk fokus centreret om tidens forhold til eksistensen. Fokus er ikke på de enkelte værker, men konsekvent på bestemmelsen af relationen mellem selv og tid og med det ærinde at påvise, at en bestemmelse af selvet er en bestemmelse af selvet som et tidsligt selv.

Bogen, der udkom på Anis i 2009, hedder som sagt Tid og eksistens. Kierkegaard og Heidegger. Der er en meget betegnende titel, og meget betegnende for forfatterens måde at skrive på. Der er ikke noget fancy eller manieret ved bogen: Tid og eksistens og Kierkegaard og Heidegger-det er det, bogen handler om. Bogen er en lettere revideret udgave af den ph.d.-afhandling, som Quist indleverede på Afdeling for Systematisk Teologi ved Det Teologiske Fakultet og Center for Subjektivitetsforskning på Københavns Universitet.

Det er en bog, der analyserer den menneskelige væren, som den kommer til udtryk hos Kierkegaard og Heidegger. Quist bevæger sig adræt rundt i begge forfatterskaber og undersøger knivskarpt ligheder og modsætninger i deres forståelse af begrebet eksistens for derigennem at udfolde sam- og modspillet mellem Kierkegaards etisk-religiøse udlægning af 'hiin enkelte' og Heideggers værdineutrale og a-religiøse analyse af den menneskelige værensform. Det er godt set, og det er godt udført, og på raffineret vis udarbejder Quist ikke blot en komparativ analyse af tid og eksistens hos Kierkegaard og Heidegger, og faktisk heller ikke en cirkulær bevægelse fra Kierkegaard til Heidegger og tilbage til Kierkegaard. Derimod danner hun en form for fuldstændighed med et samlet sigte, fordi Heideggers betoning af mennesket som værende $i$ verden er rammesættende for analysen af Kierkegaards begreber - det er med Heideggers betoning af væren som tid, at Kierkegaards begreber undersøges.

Metodisk anvender Quist en art negativ fanomenologi (som tidligere er anvendt i Arne Grøns doktorafhandling, Subjektivitet og negativitet), hvor begreberne analyseres og forstås ud fra deres egen modsætning. Umiddelbart kan det synes som en omvej, men hos Quist bliver det en genvej, fordi fokus er på begreberne, og fordi tilgangen er tematisk. 
Udgangspunktet er således en begrebsundersøgelse af tiden, hvor Quist analyserer forskellen på at forstå tiden ud fra en erfaring af tid og ud fra en strukturel bestemmelse af den menneskelige væren. Bogen har fokus på tid og eksistens, men den har samtidig et samlet sigte på Kierkegaard og Heidegger.

Bogen etablerer en forståelse af tiden og eksistensen i en bestemmelse af mennesket som eksisterende $\mathrm{i}$ og af tiden. Menneskets liv er struktureret som et fortidigt, nutidigt og fremtidigt liv, og i Quists udlægning lever mennesket som denne struktur ved at erfare sig selv som udspændt mellem livets begyndelse og afslutning. Det er den erfaring, der gør, at mennesket både lider under og formes af tiden.

Quist tager sit udgangspunkt i to centrale tekststeder hos Kierkegaard og Heidegger. Hos Kierkegaard er det "Existents lader sig ikke tænke uden Bevægelse, og Bevægelse lader sig ikke tænke sub specie aterni" og hos Heidegger "Tilstedeværen tidsliggør qua tiden sin væren”. Tekststederne peger på kvintessensen hos Quist: Begreberne tid og eksistens står i et reciprokt forhold, hvor de forklarer og tydeliggør hinanden. Forståelsen af tid indeholder immanent en analyse af mennesket som det, der kan forstå, og omvendt kræver for- ståelsen af mennesket en analyse af menneskets tidslige væren.

At Quist tager udgangspunktet og udfolder det herfra, peger endvidere på hendes overordnede betragtningsmåde, fordi det udtrykker den eksistensfilosofiske tilgang, som er vandmærket gennem hele hendes bog. Quist bruger tekststederne til at pointere, at den menneskelige væren har karakter af bevægelse, og at den dermed og derfor er knyttet til tid, samtidig med at den også må knyttes til endeligheden. De tekststeder, der efterfølgende undersøges, er således de tekststeder, hvor den menneskelige værens karakter af tidslighed betones: "Den tungeste Byrde, der blev lagt paa et Menneske [...] er i en vis Forstand Tiden". Quist bruger det til at fremhæve det dobbelte sigte, der findes i tiden som byrde: Det peger på, at mennesket bevæges, og at denne bevægelse er bestemmende for menneskets forståelse af sig selv, og samtidig peger det på, at bestemmelsen af byrde kan udfoldes nærmere ved en undersøgelse af, om mennesket kan blive en byrde for sig selv.

Byrden erfares imidlertid på forskellige måder. Den kan være knyttet til fortiden, nutiden og fremtiden: Mennesket kan slutte sig selv inde, når det ser sig bundet til fortidens synder, det kan nedbrydes af kedsomhed, når tiden synes 
lang og nølende, og det kan ængstes, når fremtiden synes truende. Quist bruger disse forhold til at vise, at et menneske ikke er sig selv på trods af tiden, men at det bliver sig selv netop gennem tiden: Mennesket må bestandigt vedkende sig den, det var, for at kunne rette sin væren fremefter. Tiden angiver derfor, at mennesket er stillet over for en opgave, som det er forhindret i at løse. Når mennesket således ikke behersker eksistensen, så er det fordi, eksistensen er knyttet til tiden: Eftersom mennesket er bevægelse, kommer det aldrig til at gribe eller eje sig selv.

Quists bog kommer dermed til at pege tilbage på den del af Kierkegaard-receptionen, hvor Michael Theunissen og Arne Grøn er to af de mest prominente navne, og den kendsgerning kommer indirekte til at pege på, at man først får det fulde udbytte af bogen, hvis man har et omfattende kendskab til den Kierkegaard-reception, som Quist står på skuldrene af, og naturligvis til Kierkegaard og Heideggers værker og til den på alle måder originale begrebsverden, som er til stede hos dem. Quist er velskrivende og indsigtsfuld, men man skal ikke forvente at få introduktioner til eller udredninger af Kierkegaards og Heideggers begreber. De forklares ikke, de anvendes. Bogen kan således på alle måder anbefales til den læser, der har det nødvendige kendskab, men det er på ingen måde her, at førstegangslæseren skal begynde.

Mens denne anmeldelse skrives er der europamesterskaber i atletik i Barcelona. Her er en af atleterne blevet beskyldt for at have dopet sig med det opkvikkende stof modafinil, der er et præparat, der stimulerer centralnervesystemet og forebygger træthed og utidige anfald af narkolepsi eller søvnapnø. Et sådan stof kunne måske være en håndsrækning for den uindviede, der alligevel giver sig i kast med Wenche Marit Quists Tid og eksistens. Kierkegaard og Heidegger, for det er bestemt ikke en bog, der "beqvemt lader sig gjennemblade under Middagssøvnen"...

RIKKE LOUISE PETERS

\section{Skabelsen af et godt samfund}

Kasper Stouring: Sammenhangskraft, Gyldendal, 2010, 216 sider, 199,- kr.

Kulturforskeren Kasper Støvring har begået en ny bog med den slagkraftige titel Sammenhangskraft. Begrebet sammenhængskraft har i de seneste år fyldt meget i samfundsdebatten - for meget er der sikkert nogen, der vil mene. Ordet dukker 